RESENHA

\title{
Participação e democracia no Brasil: da década de 1960 aos impactos pós-junho de 2013
}

\author{
Tauã Carvalho de Assis
}

GOHN, M. G. Participação e democracia no Brasil: da década de 1960 aos impactos pós-junho de 2013. Petrópolis: Vozes, 2019. 294 p.

Na obra Participação e democracia no Brasil, Maria da Glória Gohn, professora titular da Faculdade de Educação da Universidade Estadual de Campinas (UNICAMP), revisita as manifestações de junho de 2013, seus impactos societários e as ocupações das escolas públicas pelos estudantes secundaristas, em 2015-2016, a fim de "contextualizar a emergência dos jovens na cena pública como um ator sociopolítico relevante neste século, de forma um tanto quanto contraditória” (Gohn, 2019, p. 17).

A temática da participação social e política constitui-se eixo organizador do livro para se pensar a relação democracia-educação no Brasil. Para isso, a autora recorre à análise das formas históricas de participação ocorridas nos últimos 58 anos. Ainda que essa análise passe pela sociedade política e pelas forças institucionalizadas de participação no interior do Estado, a obra propõe-se a problematizar e refletir sobre as condições do atual cenário social e político brasileiro, do ponto de vista da sociedade civil, do associativismo, dos movimentos sociais e dos coletivos.

O livro divide-se em seis capítulos, agrupados em duas partes, além da apresentação e das considerações finais. A primeira parte apresenta o quadro referencial teórico da discussão e a construção das formas históricas da participação social. O capítulo 1, explora o domínio teórico-conceitual e realiza uma espécie de balanço das principais concepções já elaboradas sobre participação. Para isso, Gohn (2019) se apoia em autores clássicos e contemporâneos das ciências sociais que se têm dedicado à temática.

Para a autora, os processos participativos não ocorrem separadamente e de maneira autônoma diante das questões societárias. Ao contrário, defende que aqueles estão inscritos nos processos sociais mais amplos. Por conseguinte, o que existem são formas históricas de participação delineadas e limitadas por seus contextos.

'Universidade Federal de Goiás, Jataí, GO, Brasil. 
Os capítulos 2 e 3 tratam, então, de construir uma tipologia brasileira das formas históricas de participação social e política.

São cinco as formas históricas identificadas. O segundo capítulo descreve os quatro primeiros ciclos de protestos e de participação distintos e registrados em um período histórico de 50 anos (1960-2010). A autora discute tanto a participação no âmbito da sociedade civil (protestos políticos, movimentos sociais, coletivos, associativismo) quanto a participação institucionalizada, que ganharia relevo a partir da promulgação da Constituição de 1988, como antídoto ao "déficit" democrático.

O quinto ciclo (2013-2018), e foco central do trabalho da autora, fica por conta do capítulo 3. Nele, são analisados os protestos brasileiros então realizados a partir de junho de 2013, espaço de reivindicação de diferentes grupos e pautas, e o caleidoscópio social que os configuram, em especial: o protagonismo juvenil, o ativismo cibernético, a onda antissistema, a forte atuação dos novíssimos movimentos sociais, a presença dos diferentes discursos políticos (autonomistas, liberais, conservadores, socialistas libertários, anarquistas), a diversificação das pautas de protesto (luta por direitos, anticorrupção, educação, religião) e a polarização das convicções políticas e eleitorais.

Para Gohn (2019), os novíssimos movimentos, aqueles a partir de 2013, provocaram alterações na vida social não previstas/esperadas pelos analistas. Aponta, ainda, que os protestos desta década tiveram forte penetração social, alterando a cultura política de até então, incluindo efeitos contraditórios para a democracia brasileira, que passou a ser, mais uma vez, tensionada. Outro reflexo indicado é o esvaziamento dos espaços institucionalizados de participação, que ocorre a partir de 2015.

A pauta e a luta pelo direito a uma educação pública de qualidade se deslocam, então, da política partidária e do Estado, intermediado por suas instituições oficiais, para as ruas, que se tornaram arenas de manifestação dos sujeitos e dos coletivos. Entretanto, o que se registrou foram a elevação da polarização de diferentes projetos de educação, resultado das divergentes concepções societárias, e a retração do diálogo e da busca do consenso. Cabe ainda assinalar que as propostas governamentais não ressoaram entre os manifestantes, o que fortaleceu a aura de autenticidade, de legitimidade e de força do movimento.

$\mathrm{Na}$ segunda parte da obra, os focos de análise são a juventude, a participação e a educação. O quarto capítulo contextualiza o conceito de juventude e a ascensão dos jovens como atores sociais relevantes e de visibilidade, a partir do advento dos novíssimos movimentos. Em seguida, trabalha a cultura política de participação das juventudes, em especial os movimentos do passe livre e das contrarreformas da educação, caracterizando estes como de caráter mais autonomista, de ativismo nas redes sociais e de contestação às políticas públicas.

O capítulo seguinte retrata, historicamente, as lutas sociais e as políticas públicas em educação no Brasil. Partindo de 1873, com a primeira reunião de professores de que se tem notícias, o percurso histórico chega à presente década, analisando a ocupação das escolas públicas promovida pelos secundaristas, para então problematizar os vínculos das ocupações 2015-2016, com as manifestações de junho de 2013 e com outras organizações e movimentos políticos. 
Primordialmente, esse capítulo guarda forte relevância para os estudos das políticas educacionais e sociais brasileiras, por apresentar uma espécie de diálogo entre sociedade e Estado. Embora a autora se concentre em debater a questão pela ótica da sociedade civil, pode-se depreender do trecho tanto a relevância do Estado como agente ainda central na formulação e na implementação das políticas educacionais quanto seu papel de regulador e regulamentador da educação nacional.

O último capítulo explora e traça um paralelo entre os eventos de maio de 1968 e os de maio de 2018, guardando suas especificidades e realidades distintas. $\mathrm{O}$ texto tem como questão-chave a investigação do legado das ações coletivas de maio de 1968, na França, e busca compreender como essas manifestações influenciaram a trajetória brasileira por direitos sociais, em especial os educacionais e em relação à juventude.

Nas considerações finais, que trazem como subtítulo "Para onde segue a democracia no Brasil?", Gohn examina as principais questões da temática explorada pela obra e reafirma a tese da (re)configuração da participação na história brasileira, principalmente no pós-junho de 2013. Aqui a autora reitera que o período promoveu o surgimento de novos associativismos coletivos. Tanto quanto diversos.

Outro efeito dos protestos apontado foi a formação de alternativas políticas para as próximas eleições, ainda que estas se tenham colocado como negação da própria política. "Negando a política na representação imaginária do social, essas lideranças se firmaram como políticos"(Gohn, 2019, p. 253). Em geral, esses novos atores defenderam as teses neoliberais, o antiestatismo, a livre regulação do mercado, o combate à corrupção, o conservadorismo e a defesa pela educação.

É sobretudo o tema da educação, suas finalidades e seus meios, que seria, mais tarde, imposto como arena dos debates ideológicos. Em torno da temática, aglutinaram-se partidos políticos, gestores, organizações estatais, sindicatos e os novíssimos movimentos sociais, mas sem sucesso. Os atores não conseguiram captar ou traduzir as linhas de força do movimento em ação governamental.

A obra representa importante leitura para a compreensão do novo ciclo de lutas no campo da educação que se apresentou no início de 2019 (Gohn, 2019). Duas posições distintas se antagonizaram:

1. a gestação de um novo modelo educacional pelo governo federal, pautado na expurgação da questão de gênero, na implementação das propostas vinculadas ao Movimento Escola sem Partido e no incentivo aos parâmetros cívico-militares; e

2. a reação da sociedade civil aos bloqueios orçamentários e o posicionamento de repúdio de algumas das associações de pesquisas educacionais brasileiras à política educacional, em implementação desde então.

A posição da autora fica demarcada pela "premissa fundamental que defendemos há alguns anos: a participação da sociedade civil nas lutas pela educação não é para substituir o Estado, mas para que este cumpra seu dever: o de propiciar educação de e com qualidade para todos"(Gohn, 2019, p. 226).

Consideramos que Participação e democracia no Brasil representa importante leitura para (re)pensarmos a gestão democrática e participativa em educação em 
tempos de contração dos espaços públicos participativos no interior do aparelho estatal. Instrumento valioso para ponderarmos as ondas e os tsunamis da educação e as inúmeras manifestações de rua que já aconteceram no percurso do ano de 2019, ora como espaços de cidadania, na luta por direitos sociais (aqui a educação aparece em relevo, e depois a previdência social), ora abrigando protestos pró-governo (desencadeados por seus apoiadores e pelo próprio governo), situação sui generis que ainda exige pesquisa e reflexão teórica.

Após a leitura do livro, algumas questões ainda ficam em aberto: Seriam as ruas e os novíssimos movimentos sociais a ágora de nosso tempo? As manifestações, os coletivos e as pautas identitárias representam novas formas de relação sociedade e Estado (ainda que se diga antiestatista) para além do sistema político partidário?

A respeito da pauta educacional, resta-nos ainda inquirir se esta possui de fato capacidade aglutinadora diante da diversificação dos inúmeros movimentos sociais. E seria ela sustentável temporal e politicamente? Processaria uma reconfiguração do papel do Estado e da gestão da educação nesse novo contexto? Além disso, no quadro geral, como podemos analisar a participação no interior da gestão educacional? A obra não responde a essas questões, mas alimenta o debate e convida a novas contribuições.

\section{REFERÊNCIA}

GOHN, M. G. Participação e democracia no Brasil: da década de 1960 aos impactos pós-junho de 2013. Petrópolis: Vozes, 2019.

\section{SOBRE O AUTOR}

Tauã Carvalho de Assis é doutorando em educação pela Universidade Estadual de Campinas (UNICAMP). Professor da Universidade Federal de Goiás (UFG).

E-mail: tauacarvalho@hotmail.com

Recebido em 23 de setembro de 2019 Aprovado em 10 de fevereiro de 2020 